\title{
Sustainable Site : Kenyamanan Spasial Pada Ruang Terbuka Publik Kampus Itenas Bandung
}

\author{
Dwi Kustianingrum , Eka Virdianti , Dian Duhita Permata \\ Jurusan Arsitektur, Fakultas Teknik Sipil dan Perencanaan, ITENAS, Bandung \\ Email: dwie@itenas.co.id
}

\begin{abstract}
ABSTRAK
Ruang terbuka publik di kawasan kampus itenas terbentuk dari pola tatanan massa yang dapat bersifat katalisator bagi perkembangan interaksi dan komunitas civitas akademika.. Interaksi antar civitas akademika dapat terjadi karena kenyamanan beraktifitas. Ruang yang responsif terhadap aktifitas memiliki kriteria, salah satunya dalam kenyamanan spatial. Penelitian ini bertujuan untuk mengidentifikasi kenyamanan spatial di ruang terbuka publik itenas. Pendekatan penelitian menggunakan metoda kualitatif dengan pengambilan data melalui observasi, kuesioner dan dokumentasi di periode waktu tertentu. Metoda analisis menggunakan metoda deskriptif. Hasil penelitian teridentifikasi hanya beberapa tempat yang menjadi titik kumpul mahasiswa dengan kenyamanan spatial tercapai dengan alasan tempat tersebut masuk kategori area teduh dan nyaman. Walaupun dari sisi elemen publik space di beberapa tempat belum terlengkapi namun mahasiswa dapat menggunakan elemen lain untuk mendukung aktifitasnya.
\end{abstract}

Kata kunci: Sustainable Site, ruang terbuka publik kampus, kenyamanan spasial, Itenas.

\begin{abstract}
Public open space in the campus area is formed from the pattern of building order that can be a catalyst for the development of interaction and community academic community. Interaction among academic community can occur because of the convenience of activity. Space that is responsive to activity has criteria, one of which is in spatial comfort. This study aims to identify the spatial comfort in public space itenas. The research approach uses qualitative method with data retrieval through observation, questionnaire and documentation in certain time period. The method of analysis using descriptive method. The results of the study identified only a few places that became a student gathering point with the spatial comfort is achieved by reason of the place into the category of shady areas and comfortable. Although in terms of elements of public space in some places have not been completed but students can use other elements to support theirs activities.
\end{abstract}

Keywords: Sustainable Site, Public open space in campus, spatial comfort, Itenas. 


\section{PENDAHULUAN}

Desain berkelanjutan merupakan dasar pemikiran, "thinking as system: connectivity not fragmentation" [1] dengan pola tersebut diharapkan sebuah desain dapat lebih responsif terhadap aspek lingkungan, ekonomi dan sosial. Profesi arsitek dalam proses merancang lingkungan binaan, akan sangat bersinggungan dengan system ekologi lingkungan sekitar. Hal ini dapat menyebabkan tantangan dalam proses desain, "Bagaimana membentuk sebuah system binaan baru yang dapat terhubung dengan system yang telah berlangsung".

Proses beraksitektur menghasilkan karya arsitek dengan fungsi tertentu yang akan direspon oleh pengguna dalam bentuk aktifitas. Ruang fungsi, tidak hanya terbatas dalam ruang dalam yang terlingkupi bidang, namun dapat juga berupa ruang luar yang berfungsi untuk berbagai aktifitas. Ruang terbuka public adalah bagian dari ruang fungsi yang terbentuk dari tatanan massa bangunan dan dapat berfungsi sebagai area komunal. Menurut Gehl.J, 1996, "Life between building merupakan kehidupan yang terjadi akibat pola tatanan massa, bergabung menjadi bentuk ruang komunal dalam suatu kawasan dan seluruh ragam kegiatan, sehingga membuat kawasan tersebut lebih bermakna serta menarik" [2].

Klasifikasi ruang terbuka public dapat juga bersifat privat bergantung pada lokasi dan kepemilikan. Ruang terbuka public-privat dapat terletak pada lokasi pendidikan, komersial area ataupun perumahan. Kawasan pendidikan, yaitu kampus merupakan sample kota dalam skala kecil. Secara fisik sebuah dapat kampus terdiri dari beberapa bangunan, sarana dan prasarana. Meliputi pengguna dari beragam komunitas, budaya dengan kepentingan. Akan menjadi menarik jika kawasan tersebut, terdapat ruang terbuka public sebagai sarana dari ragam komunitas kampus untuk berinteraksi.

Institut Teknologi Nasional Bandung merupakan salah satu kampus yang memiliki lahan cukup luas di kawasan perkotaan. Terdiri dari beberapa gedung dengan civitas akademika beraneka latar belakang, budaya. Ruang terbuka public di kawasan ini, terbentuk akibat pola tatanan massa. Bagaimana ruangruang tersebut direspon oleh mahasiswa sebagai pengguna bila ditinjau dari sustainable design. Ruang terbuka yang responsif dapat memberikan kenyamanan dalam beraktifitas sehingga terjadi interaksi sosial di dalamnya. Latar belakang tersebut menjadi dasar pemikiran dari penelitian ini, yaitu untuk mengidentifikasi kenyamanan spatial pada ruang terbuka public di kawasan Itenas.

\section{TINJAUAN PUSTAKA}

Definisi yang sederhana, ruang publik dapat digambarkan sebagai tempat umum, di mana orang datang bersama-sama sebagai teman dan komunitas. Tempat dimana orang berbagi bersama dan berinteraksi tanpa melihat dan membedakan segmentasi masyarakat, ekonomi, demokrasi dan budaya. Sebuah ruang publik memberikan pengalaman yang menyenangkan dalam kegiatan mengamati berbagai bentuk aktifitas yang terjadi di sekitar tempat tersebut. Kegiatan dalam ruang tersebut dapat menciptakan interaksi antara lingkungan dan komunitas [3].

Ruang terbuka hijau merupakan bagian dari ruang publik atau ruang komunal, tempat dimana kegiatan sosial, ekonomi terjadi, dan percampuran budaya. Dari hal tersebut terlihat 3 (tiga) apek keberlanjutan yaitu : (1) Lingkungan diwakili oleh ruang publik dan konteks alam sekitar tersebut, (2) Komunitas diwakili oleh budaya dan sosial, (3) Ekonomi. Berdasarkan PPS (Project for Public Spaces), terdapat 4 (empat) kualitas utama (lihat gambar 1) yang perlu dimiliki ruang terbuka, yaitu ruang publik yang aksesibel, menumbuhkan aktivitas pengunjung, nyaman serta memiliki visual yang baik dan memiliki nilai sosial dimana setiap individu dapat bertemu satu dengan lainnya dan membawa orang ketika berkunjung [4]. 


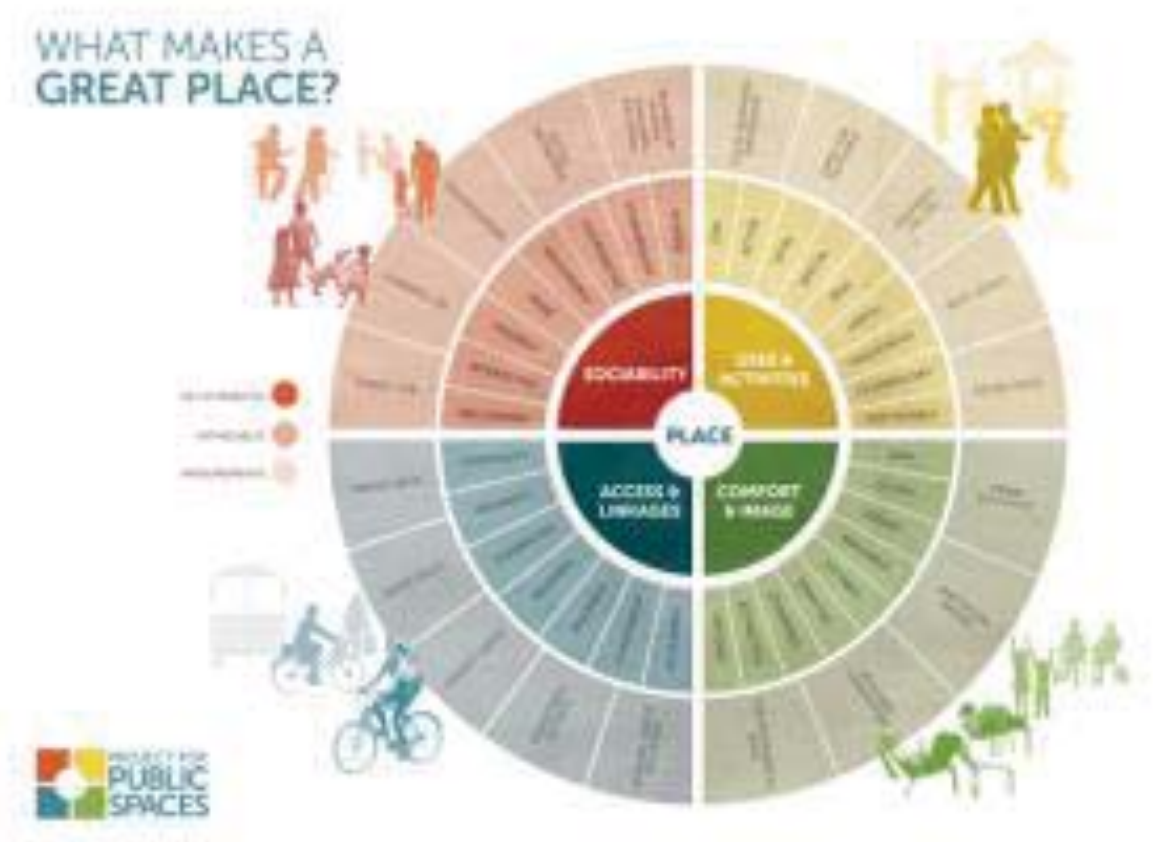

Gambar 1. Kriteria Utama Rancangan Ruang Publik [4]

Gambar di atas mendeskripsikan kriteria utama dalam merancang ruang publik yang baik adalah sociability, uses \& activities, access \& linkages, dan comfort \& image. Kriteria comfort (kenyamanan) dari sisi arsitektur merupakan salah satu indicator untuk mendapatkan pengalaman yang menyenangkan dalam ruang public. Kenyamanan fisik terkait dengan aspek [5] : (a) Spatial (ruang); (b) Visual (penglihatan, dapat termasuk estetika); (c) Auditorial (pendengaran); (d) Thermal (thermis, suhu), serta Olfactual (bau).

Untuk ruang terbuka publik, aspek kenyamanan dapat ditinjau salah satunya dari kenyamanan spatial. Aspek tersebut memberikan pengaruh yang besar terhadap berhasil atau tidaknya desain ruang publik tersebut. Kenyamanan spasial terkait dengan pemenuhan kebutuhan manusia akan ruang yang digunakan sebagai tempat menyelenggarakan aktivitasnya. Kenyamanan dapat berupa dimensi, elemen/fitur pendukung aktifitas. Manusia cenderung berpikir tentang apa yang terkait dengan dirinya dan yang ada di lingkungan sekitarnya. Kenyamanan spasial terkait langsung dengan dengan tradisi yang dipengaruhi oleh iklim serta dimensi ruang yang diperlukan. [6].

\section{METODOLOGI}

Penelitian ini merupakan studi kasus dengan lokasi di ruang terbuka Institut Teknologi Nasional (Itenas). Secara khusus obyek penelitian akan difokuskan ruang luar yang terbentuk antar massa bangunan selain fungsi parkiran. 

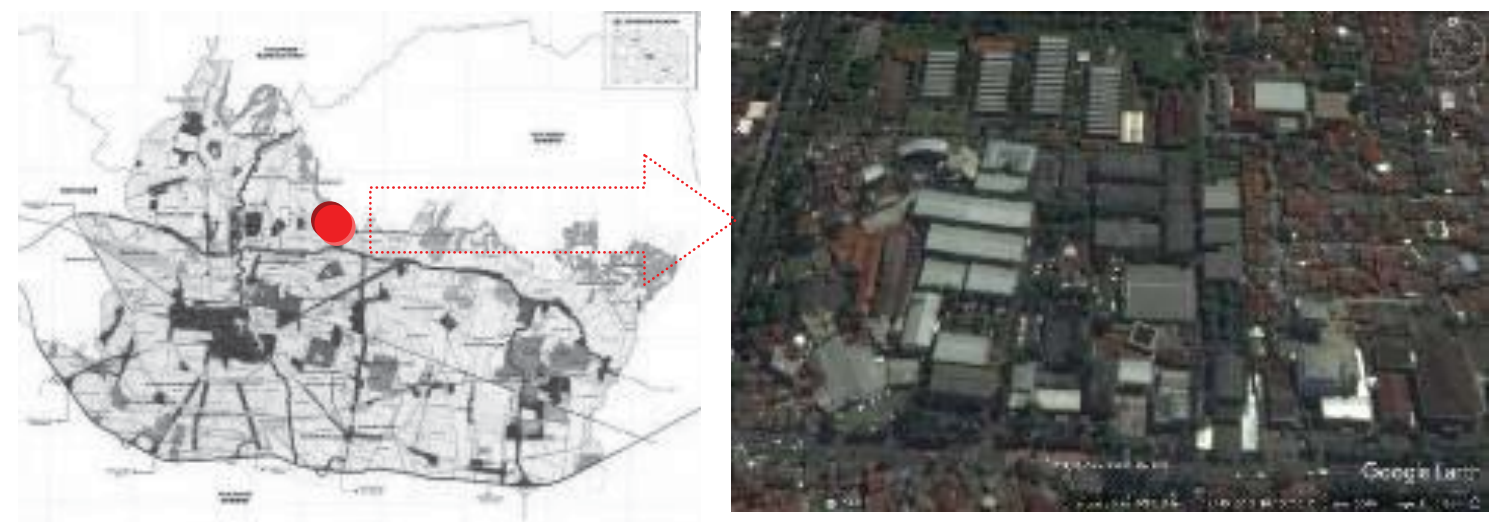

Gambar 2. Lokasi Penelitian, Kampus Itenas, Bandung Sumber : Google Earth, 2017, diolah

Pendekatan dalam penelitian ini menggunakan penelitian kualitatif. Metoda pengambilan data pada penelitian dilakukan dengan observasi, penyebaran kuesioner, dan dokumentasi pada periode waktu hari kerja dan hari libur. Periode tersebut dibagi kembali menjadi jam pengamatan yaitu jam 08.0010.00 (pagi hari); 12.00-14.00 (siang hari) dan 15.00-17.00 (sore hari). Jumlah sample responden ditarget 5 (lima) sampel per waktu pengamatan. Instrumen penelitian berupa kuesioner. Penyebaran kuesioner berkaitan dengan semua pertanyaan yang mengacu pada variabel yang akan diuji. Responden akan diambil secara purposive sampling, dari pengunjung yang mendominasi ruang terbuka tersebut. Metode analisis dilakukan secara deskriptif yang akan menggambarkan bagaimana kenyamanan spatial ruang terbuka public di kawasan itenas.

\subsection{Kondisi Ruang Terbuka dan Aktivitas}

\section{HASIL DAN PEMBAHASAN}

Institut Teknologi Nasional Bandung merupakan perguruan tinggi tergolong dalam klasifikasi urban campus yang merupakan bagian dari bentuk kota. Rencana Induk Pengembangan Itenas 2014-2030, memiliki luas tapak $18.895 \mathrm{~m}^{2}$. Sarana dan prasarana Itenas meliputi 21 unit gedung untuk kegiatan perkuliahan, praktikum, administrasi, dan kegiatan pendukung lainnya. Lingkungan kampus ditata dengan asri dan dilengkapi berbagai sarana penunjang, seperti sarana olah raga, gedung serba guna, ruang seminar, kantin, mesjid, perpustakaan, bank, internet (hot spot) dan intranet, student center, serta klinik kesehatan. Melalui hasil wawancara diprediksi Koefisien Dasar Bangunan (KDB) yang terbangun adalah $41 \%$, secara peraturan diperbolehkan maksimal $70 \%$. Sisa dari lahan tersebut diperuntukan untuk bangun-bangunan, prasarana jalan, dan area taman.

Tatanan massa bangunan di lingkungan kampus membentuk beberapa ruang terbuka. Berdasarkan hasil pengamatan di lapangan, ditemukan 20 titik ruang terbuka publik selain parkir yang dimanfaatkan oleh pengguna kampus. Lihat gambar 3. 


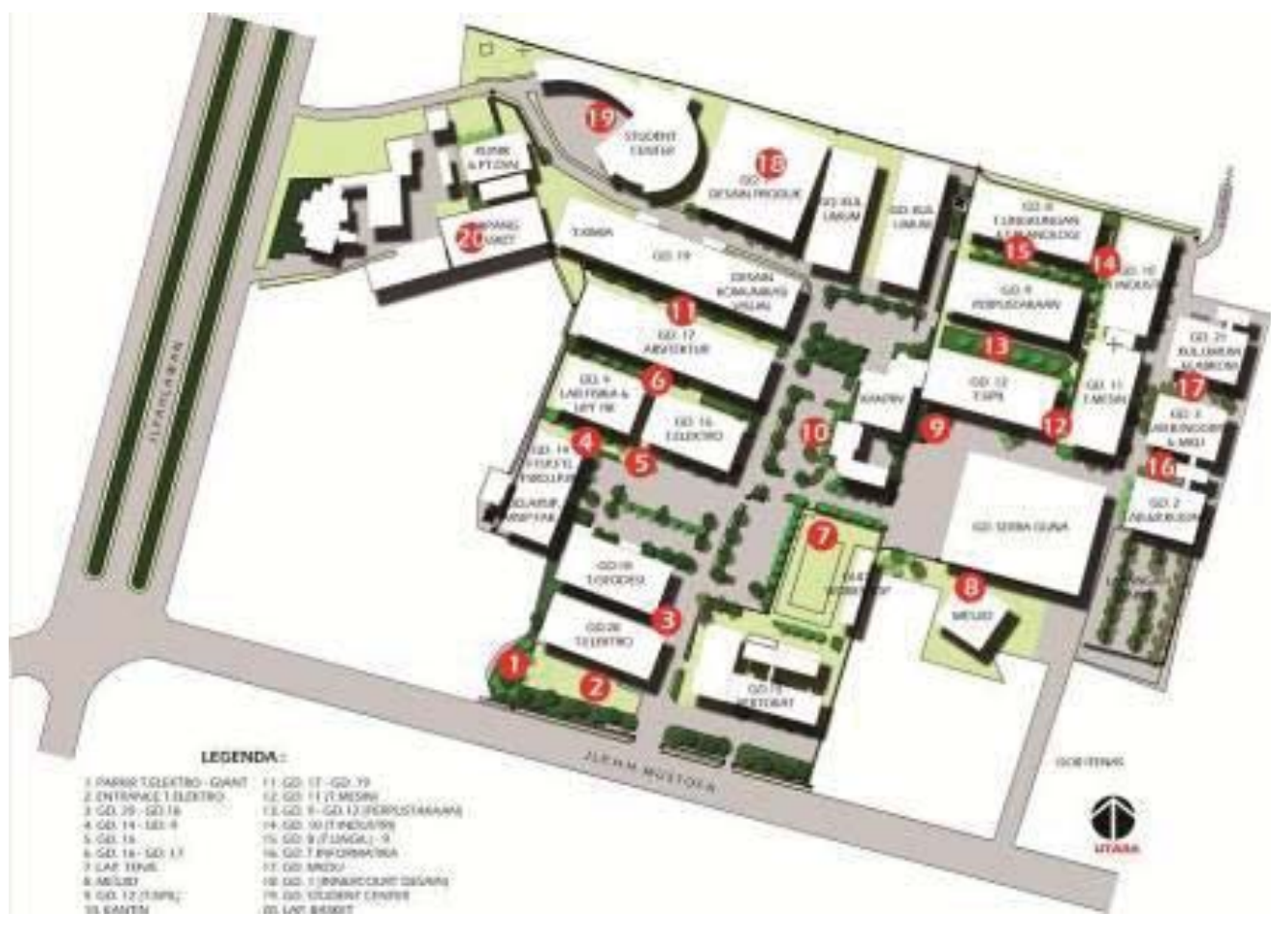

Gambar 3. Ruang Terbuka di Itenas

Ruang terbuka publik ini sebagian besar berfungsi sebagai tempat duduk, diskusi dan makan. Aktivitas di ruang terbuka publik dimanfaatkan sesuai fungsinya, yaitu ruang terbuka yang berlokasi 1, 2, 3, 4, $5,6,8,9,10,11,12,13,14,15,18,19,20$. Dari hasil survey mayoritas pengguna adalah mahasiswa kampus Itenas,pada hari kerja. Sedangkan untuk hari libur terdapat pengguna dari luar kampus seperti anak sekolah dasar dan pengantar peserta USM. Tidak hanya sebagai tempat diskusi dan makan, area ruang terbuka publik ini juga biasa dimanfaatkan sebagai tempat untuk menunggu kuliah pada waktu berikutnya.

Pengamatan terhadap pengunjung ruang terbuka publik dilakukan pada 2 periode waktu, yaitu pada saat hari kerja serta hari libur (dapat dilihat pada gambar 4). Sebaran titik kumpul pada hari kerja lebih banyak terjadi di lokasi 3, 4, 6, 8, 13, 14, 15, 19, 20. Lokasi titik kumpul ini tersebar hampir merata di area entrance (lokasi 3, 11, 15), di dalam (lokasi 18) dan di antara gedung perkuliahan (lokasi 4,6,14,15) serta berdekatan dengan fasilitas umum (lokasi 8, 19, 10, 20). 


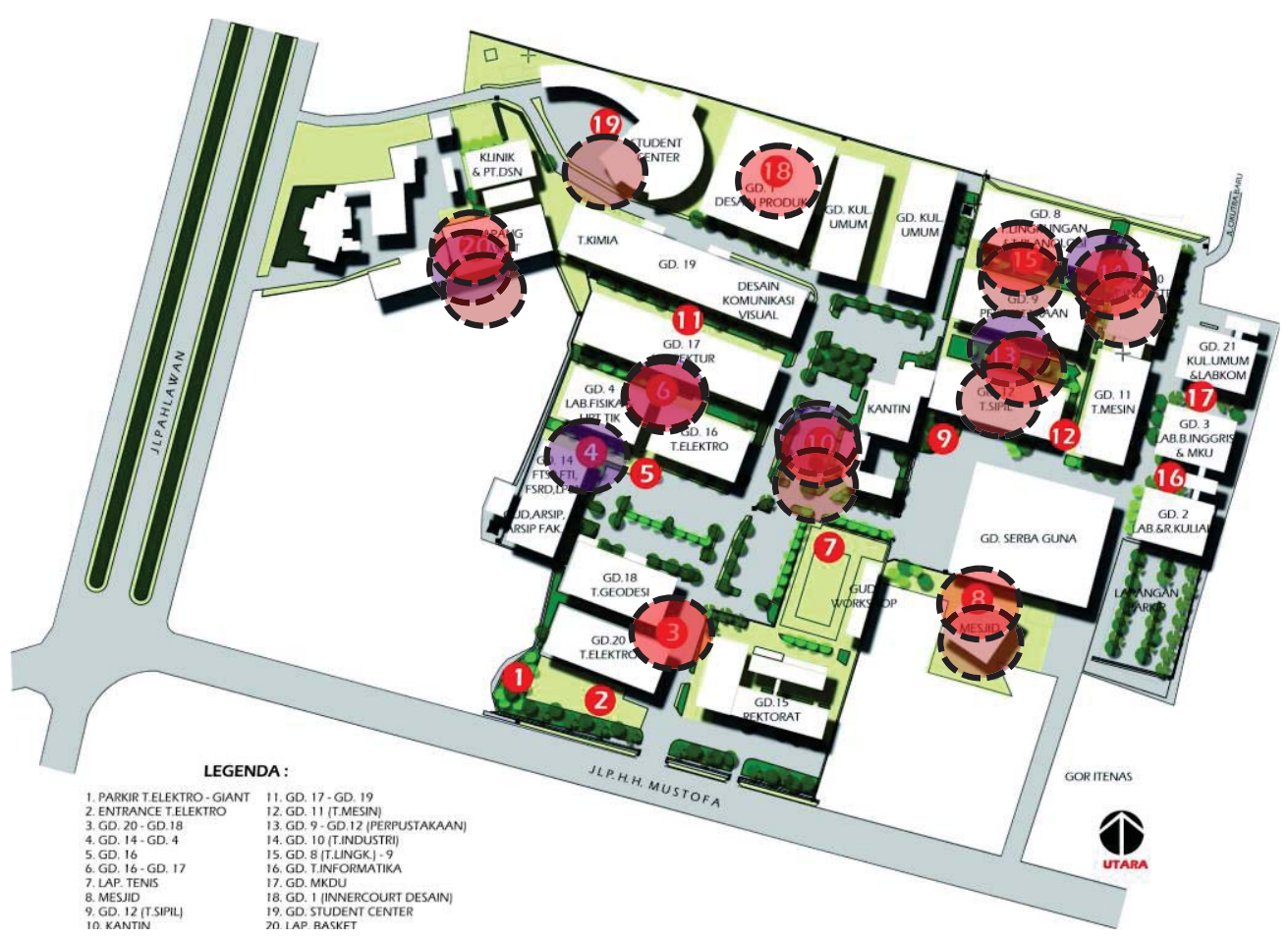

Gambar 4 .Sebaran Titik Kumpul Pada Hari Kerja

Sebaran titik kumpul pada saat hari libur ditemukan lebih sedikit. Area ruang terbuka yang paling banyak dikunjungi bersifat publik, berdekatan dengan fasilitas umum, yaitu lokasi 1, 3, 5, 8, 10, 20 . (Lihat gambar 5)

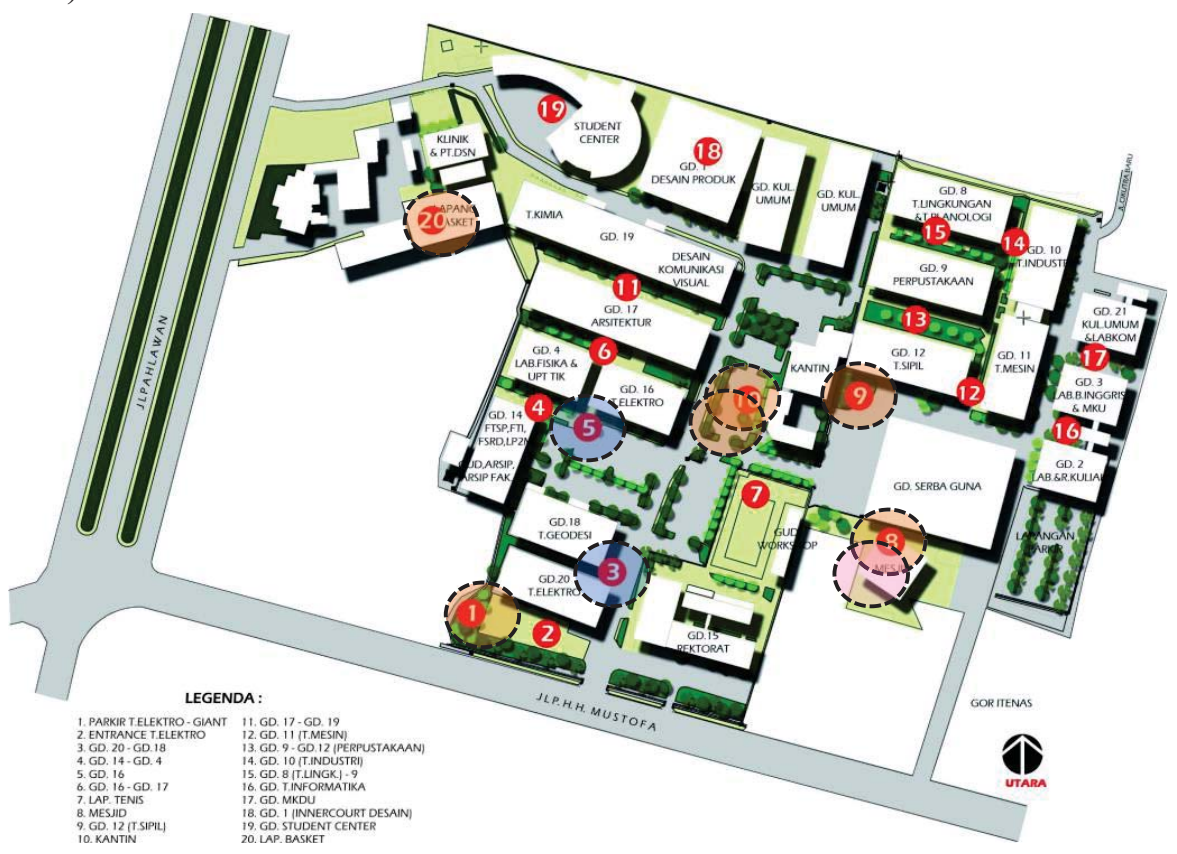

Gambar 5. Sebaran Titik Kumpul Pada hari Libur

Dari hasil pengamatan terdapat ruang terbuka dimanfaatkan sesuai fungsinya, beberapa ruang terbuka Itenas tidak termanfaatkan secara optimal. seperti di lokasi 7, 16, 17. Pada tiga lokasi tersebut tidak terlihat aktifitas dari pengguna. Aktifitas ruang terbuka publik pada kawasan kota dan kawasan 
kampus memiliki perbedaan prioritas aktivitas. Bila pada ruang terbuka publik di kawasan kota pengguna memerlukan pemandangan (view) menarik terhadap sekeliling kawasan, namun pada ruang terbuka publik kawasan kampus mahasiswa, hasil pengamatan dalam beraktifitas tidak memerlukan pemandangan (view) menarik terhadap sekelilingnya.

\subsection{Kenyamanan Spasial Ruang Terbuka Itenas}

Ruang terbuka publik Itenas memiliki beberapa ragam bentuk serta dimensi. Masing-masing ruang terbuka memiliki beberapa karakter berbeda sesuai lokasi, antara lain ruang terbuka di depan gedung, di antara gedung, di dalam gedung, di area fasilitas umum serta di koridor. Ruang terbuka tersebut dilengkapi dengan beberapa elemen hardscape dan softscape, antara lain : tempat duduk, meja, perkerasan, kanopi, pot (bak) tanaman serta vegetasi.

Ruang terbuka di depan gedung ini terletak di depan gedung perkuliahan. Masing-masing ruang terbuka dilengkapi dengan vegetasi, kanopi, perkerasan penutup tanah baik berupa beton, paving block maupun keramik, tempat sampah, area duduk berupa meja dan bangku serta beberapa vegetasi baik pohon, perdu, semak maupun rerumputan. Vegetasi bertajuk lebar berada di atas area duduk (meja dan bangku beton). Sedangkan beberapa tanaman perdu dan semak baik yang di atas tanah maupun merambat menjadi bagian dari area masuk gedung. Perbedaan elevasi antara perkerasan menuju ruang terbuka publik dipisahkan dengan trap serta ramp beton. Aktivitas pada ruang terbuka publik di depan gedung perkuliahan cenderung aktif, dimana mahasiswa biasanya duduk berkelompok melakukan diskusi menunggu waktu perkuliahan serta mengerjakan tugas. Lihat gambar 6.

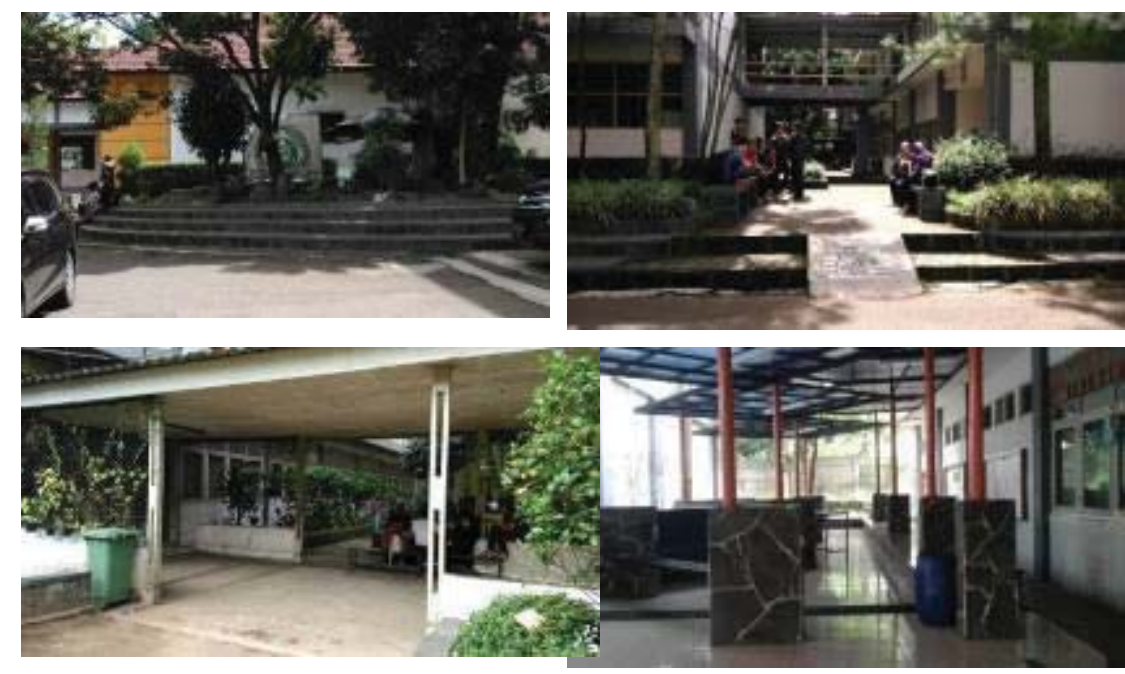

Gambar 6. Ruang Terbuka di Depan Gedung yang Diminati Menjadi Titik Kumpul

Ruang terbuka di antara gedung mayoritas berbentuk linear, mengikuti bentuk dari panjang gedung. Ruang terbuka ini juga dilengkapi dengan elemen hardscape berupa bangku beton, perkerasan paving block dan keramik, kanopi, tempat sampah, serta elemen softscape berupa pohon bertajuk, perdu, semak dan rumput. Bangku beton di beberapa ruang terbuka telah didesain dengan material beton, kayu dan besi baik berpenutup atap/kanopi metal maupun vegetasi bertajuk. Bangku/area duduk pada ruang terbuka disediakan berderet yang dipisahkan oleh vegetasi. Aktifitas ruang terbuka ini biasanya dimanfaatkan sebagai area duduk, diskusi, menunggu perkuliahan, serta mengerjakan tugas. Ruang terbuka di antara gedung yang berupa ruang terbuka hijau, titik kumpul mahasiswa biasa dilakukan di samping area hijau/rabat beton keliling bangunan secara berkelompok. Lihat gambar 7. 

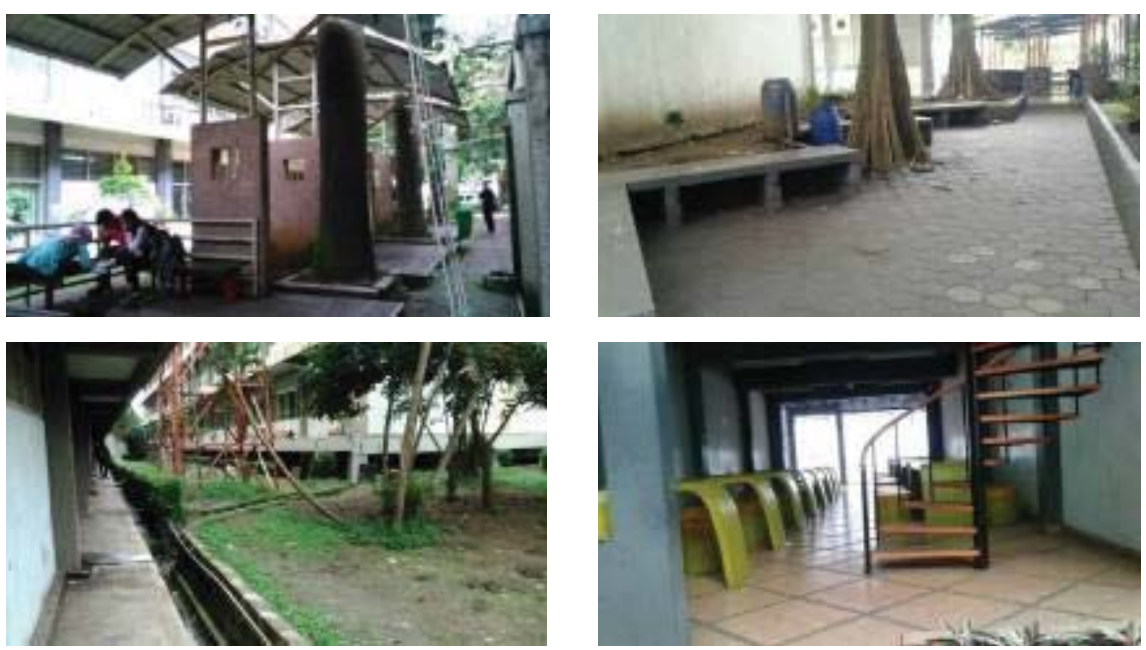

Gambar 7. Ruang Terbuka di Antara Gedung

Ruang terbuka di dalam gedung memiliki karakter yang berbeda dengan ruang terbuka lainnya. Ruang terbuka ini bersifat privat karena berupa hall yang berada di tengah bangunan serta dikelilingi oleh koridor. Void pada area ruang terbuka berfungsi memasukkan sinar matahari dan ventilasi pada area tersebut, dapat dilihat pada gambar 8. Elemen lansekap pada ruang terbuka cukup minimalis, terdiri dari penutup tanah berupa paving block, keramik, serta vegetasi merambat. Beberapa titik kumpul mahasiswa pada area ini dilakukan di sisi ruang terbuka karena menghindari sinar matahari yang masuk melalui void. Kegiatan yang dilakukan antara lain mengerjakan tugas, berdiskusi, makan dan bermain gitar.
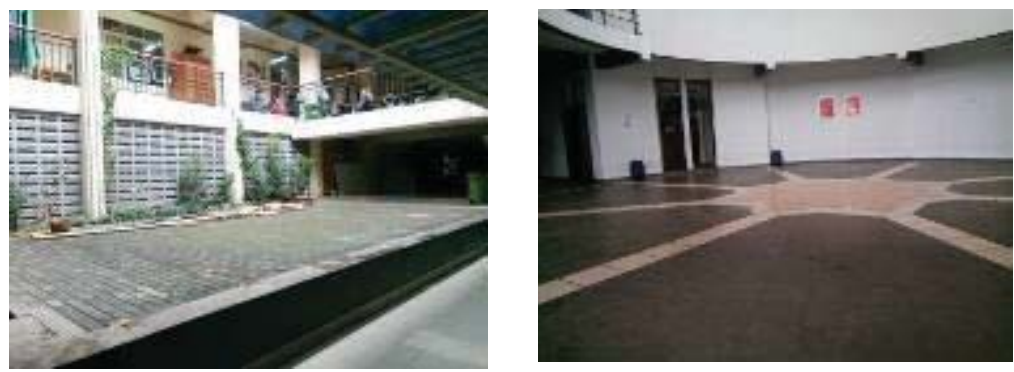

Gambar 8. Ruang Terbuka Di Dalam Gedung

Ruang terbuka di area fasilitas umum dilengkapi dengan elemen lansekap berupa bangku/tribun beton, bak tanaman yang juga dapat dimanfaatkan sebagai area duduk, kanopi, paving block serta vegetasi. Pengunjung pada area ini lebih beragam, karena sifatnya yang lebih publik dibandingkan ruang terbuka yang berdekatan dengan gedung perkuliahan (lihat gambar 9). Aktivitas ruang terbuka yang dilakukan antara lain duduk, berdiskusi, makan, berolahraga, menunggu. Pemanfaatan tribun (gambar 9(a)) oleh mahasiswa dari berbagai jurusan hampir dilakukan setiap saat meskipun tidak adanya kegiatan kuliah. Area Tribun dan Area duduk (gambar 9(c)) menjadi tempat yang dikunjungi oleh pengguna luar kampus.
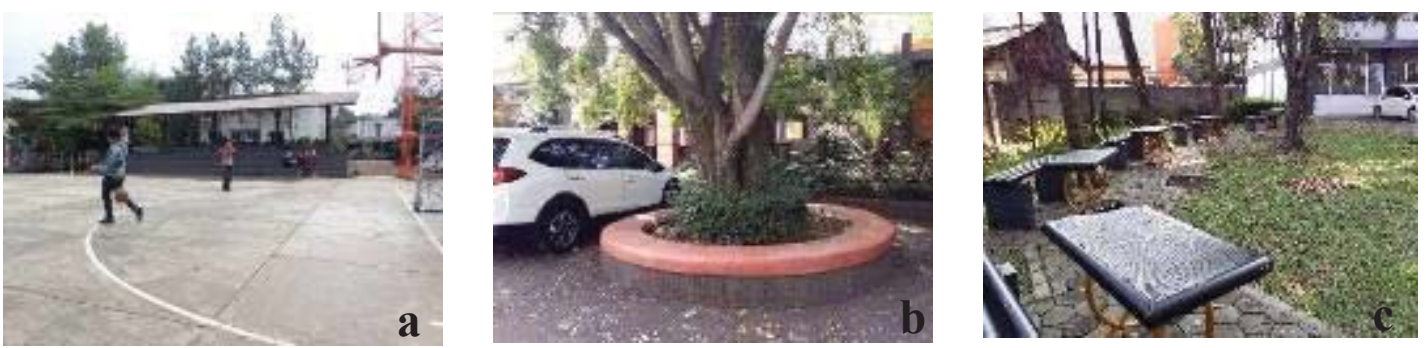

Gambar 9. Ruang Terbuka di Fasilitas/Sarana Umum

Jurnal Itenas Rekayasa - 198 
Aktifitas/titik kumpul mahasiswa seringkali juga dilakukan pada koridor penghubung. Area ini tidak didesain khusus sebagai area berkumpul, namun mereka memanfaatkan dinding dan kolom basement serta perbedaan elevasi lantai sebagai area duduk. Elemen lansekap pada area ini berupa hardscape yang terdiri dari kanopi serta perkerasan penutup tanah, dan softscape berupa vegetasi semak dan perdu. Lokasi titik kumpul ini tidak jauh dari gedung perkuliahan. Aktivitas mahasiswa pada ruang terbuka ini antara lain dudu, berdiskusi dan makan. Lihat gambar 10.
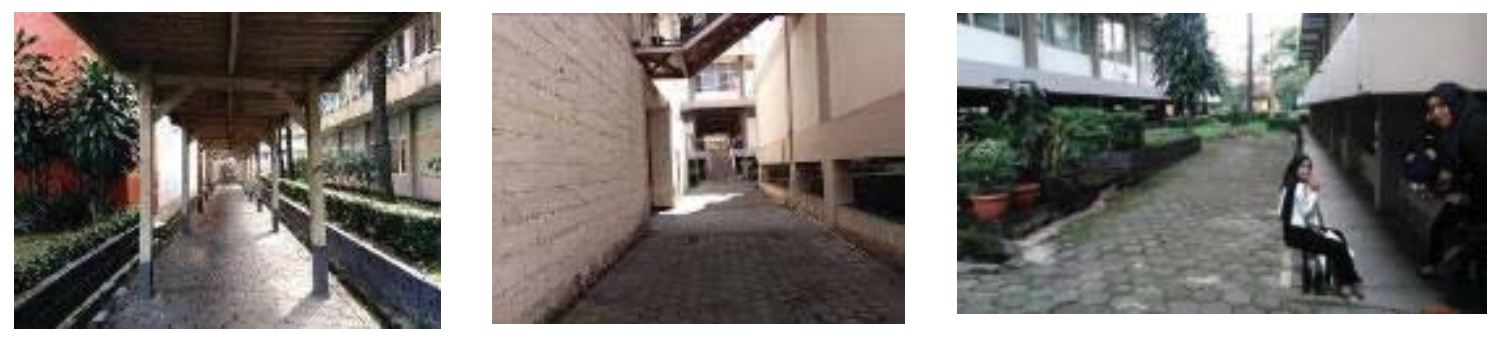

\section{Gambar 10. Ruang Terbuka di Area Koridor Pertemuan Gedung}

Pada saat dilakukan pengamatan, beberapa ruang terbuka publik di Itenas ditemukan kurang termanfaatkan dengan optimal. Hal ini diketahui karena jumlah pengunjung pada area tersebut cenderung tidak ada sehingga menjadikan ruang terbuka menjadi pasif, pada gambar 11. Elemen hardscape dan softscape pada area ini cukup lengkap seperti bangku beton, bak tanaman, pohon bertajuk, perdu, rumput serta perkerasan. Lokasi ruang terbuka ini tersebar di antara gedung perkuliahan serta berdekatan dengan fasilitas umum. Beberapa ruang terbuka pasif ini (pada gambar 11(b) dan 11(d)) terkadang dimanfaatkan sebagai area parkir kendaraan roda empat.
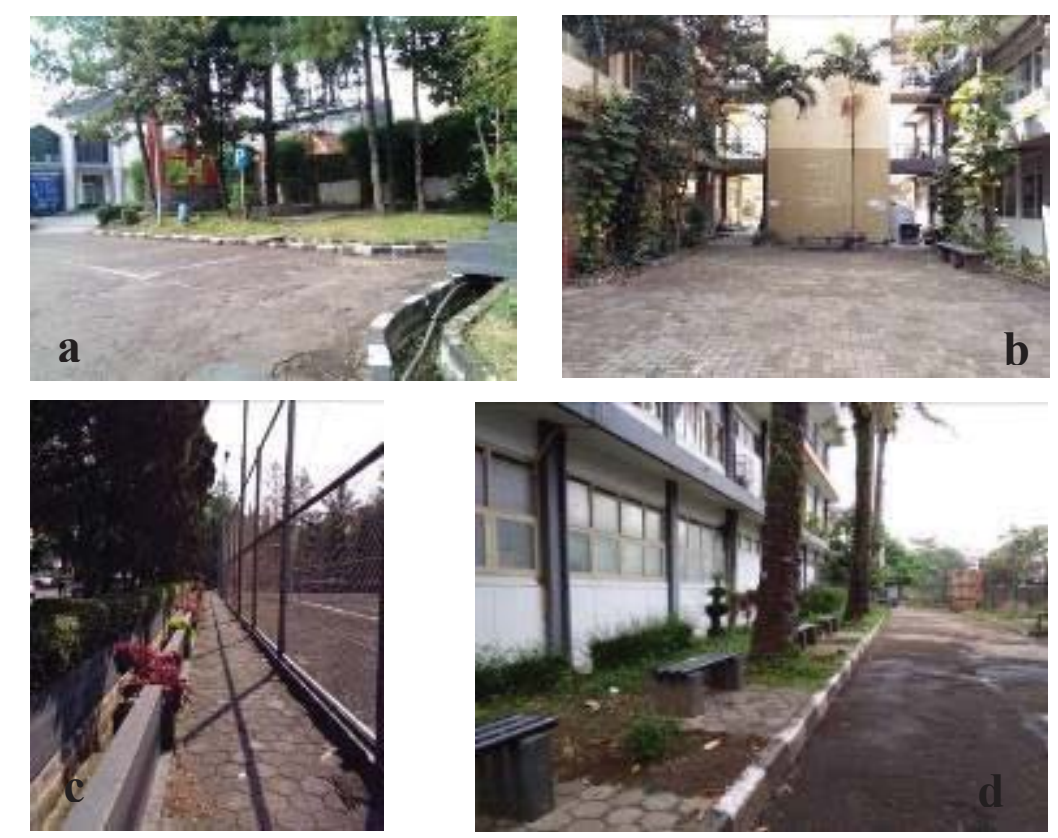

Gambar 11. Ruang Terbuka Publik yang Pasif

Analisis di atas memberikan gambaran mengenai elemen fisik ruang terbuka publik di itenas. Elemen fisik ini memberikan efek kenyamanan spatial bagi pendukung aktifitas dan iklim yang menyenangkan bagi pengguna. Hampir di tiap area terdapat elemen hardscapes dan softscape ruang publik. Elemen tersebut dapat berupa elemen bangku,vegetasi dan lainnya. Keunikannya terdapat ruang publik yang 
tidak terdapat elemen tersebut namun terespon baik oleh pengguna, sehingga aktifitas di area tersebut aktif. Berdasarkan pengamatan, respon tersebut diakibatkan adanya iklim mikro (thermal) yang nyaman. Ruang terbuka yang aktif terjadi pada area yang terbayangi (daerah pembayangan) sehingga panas matahari tidak langsung masuk ke area tersebut. Daerah pembayangan tersebut diakibatkan oleh elemen vegetasi, kanopi, dan jarak bangunan.

\subsection{Persepsi Kenyamanan Berdasarkan Responden}

Untuk melihat persepsi kenyamanan maka perlu dilihat tujuan responden datang ke ruang publik. Hal tersebut berkaitan dengan terbentuknya suatu fungsi ruang komunal dan unsur-unsur tersebut terhubung dengan satu dan lainnya yaitu (1) Aktifitas, (2) Manusia, (3) Pikiran menjadi sebuah setting [7]. Setting tersebut dapat membuat sebuah situasi zone nyaman. Pada saat hari kerja, ketika berlangsungnya kegiatan perkuliahan, pengunjung paling banyak sebanyak $38 \%$ bertujuan untuk aktifitas berdiskusi dan menunggu bersama. Pengunjung paling sedikit dengan jumlah $3 \%$ bertujuan datang karena kebiasaan serta bermain skateboard. Sedangkan pada saat hari libur, pengunjung terbanyak dengan prosentase $46 \%$ bertujuan untuk nongkrong dan bersantai, serta $5 \%$ pengunjung datang dengan tujuan menunggu/menemani teman serta mengerjakan tugas. Hasil data pengamatan dapat di lihat gambar 13.

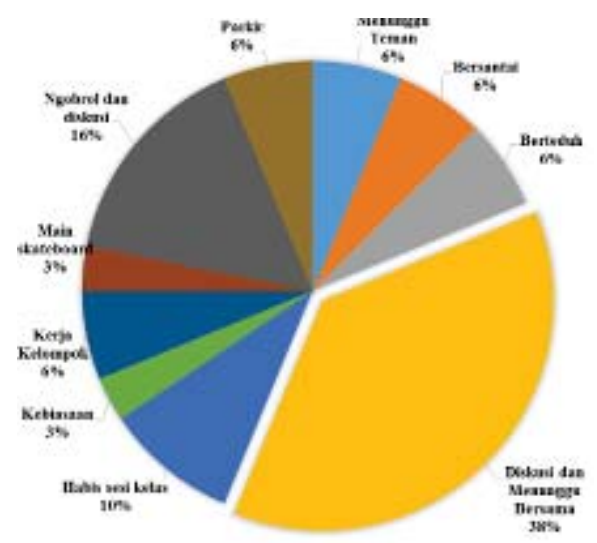

(a)

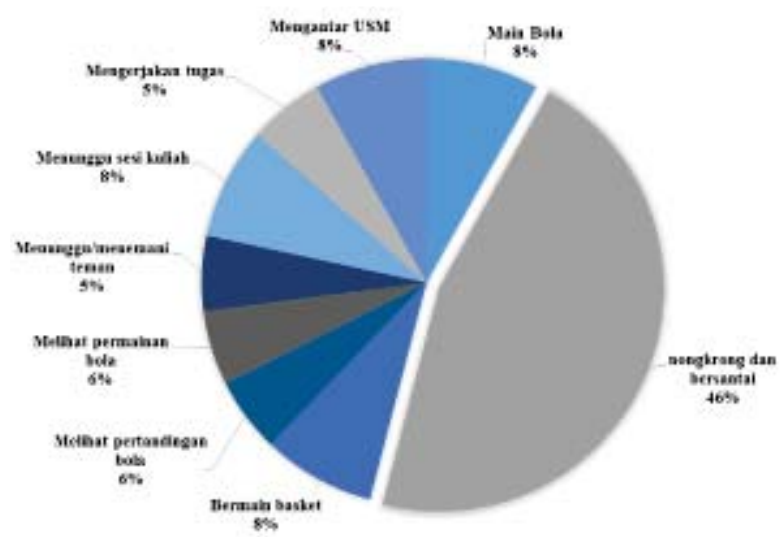

(b)

\section{Gambar 12. Tujuan Responden ke Ruang Publik Pada Hari Kerja (a) dan Hari Libur (b)}

Dari analisis di atas dihasilkan bahwa tujuan pengguna di hari kerja adalah berdiskusi dan menunggu, sedangkan hari libur adalah untuk nongkrong dan bersantai. Situasi yang harus didapatkan pada area publik tersebut adalah berupa setting yang menjadi persepsi dari pengguna untuk mendukung aktifitas. Penyebaran kuesioner pada pengunjung ruang terbuka publik Itenasi di 20 lokasi, diperoleh data bahwa pengunjung datang ke ruang terbuka memiliki beragam alasan, yaitu $52 \%$ pengunjung merasa teduh, $17 \%$ merasa nyaman, $7 \%$ merasa tenang, $4 \%$ merasa nyaman untuk berdiskusi, $3 \%$ menyukai area hijau, 3\% merasa dekat dengan jurusan dan 14\% memanfaatkan area duduk. Mayoritas pengunjung yang datang ke area ruang terbuka publik karena tempat yang teduh. Sedangkan minoritas pengunjung mencari ruang terbuka yang hijau dan dekat dengan jurusan masing-masing. Lihat gambar 12. 


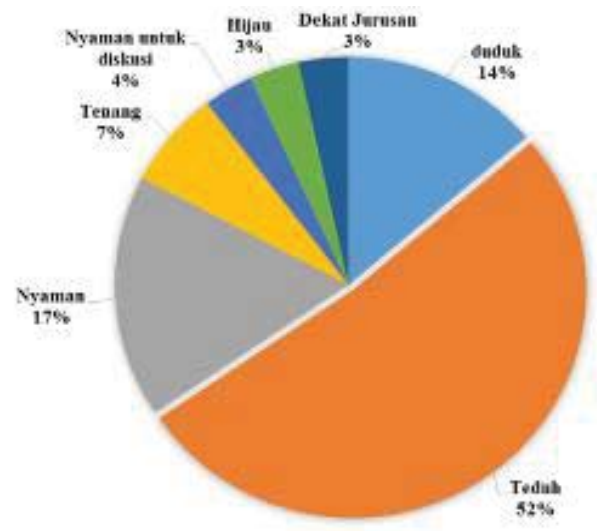

Gambar 13. Alasan Responden Memilih Tempat

Hasil olahan data tersebut dapat diketahui alasan responden dalam memilih tempat terbuka publik yaitu untuk mendukung aktifitasnya. Alasan yang paling utama dan bersifat umum adalah zone tersebut teduh, nyaman dan dapat beraktifitas duduk. Hal ini menunjukan bahwa manusia cenderung berpikir tentang apa yang terkait dengan dirinya dan yang ada di lingkungan sekitarnya [5], kenyamanan spasial terkait langsung dengan dengan tradisi yang dipengaruhi oleh iklim, disini terwakili oleh teduh dan nyaman dan dimensi ruang yang diperlukan meliputi nyaman dan tempat untuk duduk. Walaupun di beberapa ruang terbuka yang diminati, belum dilengkapi tempat duduk namun adanya elemen pengganti misalnya tembok pagar basement dan tangga, dapat memjadi sarana pendukung aktifitas pengguna.

\section{KESIMPULAN}

Ruang terbuka publik di lingkungan kampus sangat penting bagi mahasiswa Itenas sebagai pengguna utama. Dalam penelitian ini, disimpulkan bahwa ruang terbuka publik tidak harus didesain dengan estetika, namun yang terpenting adalah area tersebut dapat mendukung aktifitas dan kenyamanan beraktifitas. Aktifitas ruang publik kampus, terfokus pada duduk dan berdiskusi. Sehingga kenyamanan spatial yang dibutuhkan adalah elemen untuk mendukung aktifitas duduk dan diskusi. Aspek lain adalah iklim mikro yang membuat nyaman aktifitas tersebut. Terbukti pada ruang terbuka yang aktif terjadi pada dominasi daerah pembayangan sehingga panas matahari tidak langsung masuk ke area tersebut. Ruang pasif terjadi pada area yang langsung terpancar matahari, walaupun ada ruang pasif yang menjadi area pembayangan.

\section{UCAPAN TERIMA KASIH}

Ucapan terima kasih disampaikan khusunya pada LPPM ITENAS yang telah memberikan konstribusi berupa kesempatan dan penyediaan dana penelitian. Kepada mahasiswa dan responden yang telah berkontribusi sehingga kegiatan penelitian ini berjalan lancar.

\section{DAFTAR PUSTAKA}

[1] Daniel E Wiliama, 2007, Sustainable Design, Ecology, Architecture and Planning, John Willey \& Sons. Inc

[2] Gehl. J, 1996, Life Between Building,Using Public Space, Island Press, Washington DC

[3] Amit Bhatia (2015), Placemaking;Creating aplace of sense and sense of place ,Architecture Research Paper

[4] http://kotahijau.id/knowledge/detail/menciptakan-ruang-publik diakses 18 April 2017

[5] Karyono, 2010, Kenyamanan Termal dan Penghematan Energi; Teori dan Realisasi dalam Desain 
dalamhttps://www.researchgate.net/publication/305188224_kenyamanan_termal_dan_penghemata n_energi_teori_dan_realisasi_dalam_desain_arsitektur diakses 28 September 2017.

[6] Karyono. Tri Harso, 2016,"Bentuk, Teknologi, Kenyamanan dan Penggunaan Energi", Arsitektur Tropis, Penerbit Erlangga.

[7] Purwanto. E, 2007, Rukun Kota:Ruang Perkotaan Berbasis Budaya Guyub, dalam Purwanto,E, 2012, Pola Setting Ruang Komunal Mahasiswa Arsitektur Fakultas Teknik Universitas Dipenogoro, Seminar Nasional Riset dan Perencanaan,\#2, 13 Oktober 2012, Yogyakarta 